\title{
Making Allogeneic Bone Marrow Transplantation Available to Patients in Developing Countries: The Mexican Experience
}

\author{
Guillermo J. Ruiz-Argüelles*, ${ }^{* 1}$ and David Gómez-Almaguer ${ }^{2}$ \\ ${ }^{1}$ Centro de Hematología y Medicina Interna, Clínica Ruiz de Puebla, Puebla, Mexico \\ ${ }^{2}$ Hospital Universitario de Monterrey, Universidad Autónoma de Nuevo León, Monterey, Mexico
}

\begin{abstract}
Non-myeloablative allogeneic stem cell transplantation (NST) has been one of the most exciting developments in the treatment of hematologic malignancies in the last years. Since 1999, we have chosen to employ in México a regimen to conduct NST, introducing some changes with the main goal of decreasing the cost of the procedure and in turn, making it available to a larger number of patients in developing countries. Using this method we have done over 400 allografts in Latin American patients with different both malignant and non-malignant diseases: Chronic myelogenous leukemia, acute myelogenous leukemia, acute lymphoblastic leukemia, myelodysplasia, thalassemia major, relapsed Hodgkin's disease, Blackfan-Diamond syndrome, adrenoleukodystrophy, Hunter's syndrome, aplastic anemia and several solid tumors. In the whole group, the median granulocyte recovery time to $0.5 \times 10^{9} / \mathrm{L}$ was 13 days, whereas the median platelet recovery time to $20 \times 10^{9} / \mathrm{L}$ was 12 days. Around one third of the patients did not need red blood cell transfusions and also one third did not need platelet transfusions. In more than $70 \%$ of cases the procedure could be completed totally on an outpatient basis. The follow up time of the patients ranges between 30 and 2000 days. Approximately $50 \%$ of the allografted individuals have developed acute graft versus host disease (GVHD), whereas around 30\% developed chronic GVHD. The median post-allograft overall survival (SV) has not been reached and the 2000 day overall SV is $54 \%$, the 100-day mortality being 16\%. In the whole group of patients, the median cost of each NST was 18000 USD, a figure which contrasts with that informed from developing countries. More than $95 \%$ of the patients who were allografted in México and Latin America using this method could not have afforded the cost of a conventional or more expensive stem cell transplant; accordingly, this procedure has enabled doctors in México and Latin America to offer this therapeutic approach to a larger number of individuals.
\end{abstract}

\section{INTRODUCTION}

Over the last decades, Latin America has undergone a radical social, economical and demographic transformation. Non communicable diseases such as cancer are now a leading cause of death; the growth in the number of patients with cancer, unfortunately has not been paralleled by the increase of resources devoted to health. Sophisticated cancer treatments such as bone marrow transplantation was accessible to a minority of patients, mainly because of its cost. In the last ten years, by means of breaking several dogmata, we have been able to offer this therapeutic modality to patients in México and Latin America who could not have afforded it.

\section{a) The Dogmata}

Dogmata are principles, maxims or tenets; settled opinions adopted through authority instead of reason or experience. The progress and evolution of knowledge has very frequently relied on the breakage of dogmata [1]. Historically, the development of allogeneic hematopoietic stem cells (HSC) transplantation has relied on high dose myeloablative chemo or radiotherapy with three main dogmatic goals: 1) To eradicate underlying disease, 2) to create bone marrow space for the incoming HSC, and 3) to suppress the

*Address correspondence to these authors at the Centro de Hematología y Medicina Interna, 8B Sur 3710, 72530, Puebla, Mexico;

E-mail: gruiz1@clinicaruiz.com recipient's immune system in preparation for the allograft so that rejection of the donor stem cell graft does not occur [2].

\section{b) The Broken Dogmata}

The evolution of knowledge has proven that the first two above mentioned dogmata were wrong. In 1978, Odom et al. [3] described two patients with acute lymphoblastic leukemia who achieved a remission as a result of the development of graft versus host disease (GVHD). The concept of "graft versus leukemia" effect was then introduced. Later on, researchers from the group of the Nobel-Laureate, Dr. E. Donnall Thomas in Seattle, U.S.A, published a paper on the antileukemic effect of the GVHD [4]; this publication is now considered as one of the landmark papers in hematology of the twentieth century [5]. The documentation that donorlymphocyte infusions (DLI) with no additional chemotherapy following induction of host versus graft unresponsiveness resulted in remission, thus suggesting that once given the chance by prevention of rejection, alloreactive lymphocytes can eliminate leukemia, a concept entertained by Kolb et al. [6] and Slavin et al. [7, 8] was followed by focusing on durable engraftment of lymphocytes rather than myeloablation of tumor cells, resulting in the development of the nonmyeloablative stem cell transplantation (NST) methods starting in Jerusalem and then in Houston $[9,10]$. Accordingly, it is now well known that the anti-tumor effect of the GVHD induced by HSC allografts is responsible for the control of certain malignancies, and that HSC create their own marrow 
space through GVHD reactions [5-17]. We have learned that certain malignancies are more susceptible than others to the graft versus tumor effect; for example: Chronic myelogenous leukemia is substantially more sensitive to this effect than acute lymphoblastic leukemia [13, 14], this being probably one of the reasons of the different results obtained when allografting individuals with these diseases.

\section{c) The Consequences of Breaking Dogmata}

Having proved that the graft versus tumor effect is responsible for the control of certain malignancies in individuals given allogeneic HSC grafts the obvious question was: It is possible to induce graft versus tumor effect by allogeneic HSC without producing a severe damage to the recipient's bone marrow, immune system and other organs? The answer to this question is yes; it is now well known that current intensive and toxic cytoreductive conditioning therapy can be replaced by nonmyeloablative immunosuppression to facilitate allogeneic engraftment; in lieu of intensive chemotherapy before transplantation, engrafted donor $\mathrm{T}$ cells are used to accomplish the task of eradicating the host's malignant cells [5-19].

2) Widespread application of HSC transplantation had been limited by the toxicity associated with the myeloablative conditioning regimens. In attempts to achieve maximal tumor eradication, conditioning regimens had been intensified to a point at which serious nonhematopoietic organ toxicities were common and resulted in morbidity and mortality [19]. In addition, the pancytopenia induced by the high-dose regimens carries the risks of serious and even lethal infections despite the use of prophylactic broadspectrum antibiotics; even more, the regimen-related toxicity, particularly to the gut, liver and kidney, frequently restricts the ability to give optimal postgrafting immunosuppression therapy, which is necessary to avoid GVHD. As a result, at most transplant centers, the severity of the complications from myeloablative chemotherapy and allografts had limited their use to relatively young and strong individuals aged less than 50 or 55 years. Stemming from the fact that former intensive and toxic cytoreductive conditioning therapy can be replaced by nonmyeloablative immunosuppression to facilitate allogeneic engraftment, it is now possible to allograft individuals aged, debilitated or with comorbidities [5-19].

3) Another salient point which is frequently overlooked in papers dealing with bone marrow transplantation coming from developed countries is the cost of the procedure. In our experience (vide infra), nonmyeloablative stem cell transplantation (NST) is substantially cheaper than conventional ablative stem cell allografting [17,19-31]; as a result, allogeneic HSC can be offered now to more patients as a therapeutic option, this observation being critical for individuals living in developing countries, such as most inhabitants in Latin America. The fact that over two thirds of the inhabitants of the world live in developing countries should not be forgotten.

\section{d) The ways of Breaking these Dogmata}

Many transplantation groups have reported encouraging results using a number of reduced-intensity or nonmyeloablative conditioning regimens for patients with hematological malignancies and solid tumors [6-17]. Different approaches have been used to conduct NST: The Jerusalem approach, the Houston approach, the Bethesda approach, the Genoa approach, the Boston approach, the Seattle approach, the Dresden approach, the London approach and the Mexican approach $[32,33]$; all these approaches address the immunosuppressive effect more than the myeloablative effect of the conditioning regimens.

\section{e) The Mexican way to Break these Dogmata}

In 1999, we elected to employ a regimen to conduct NST, based in those employed in Jerusalem [7], Houston [6] and Genoa [34], introducing some changes with the main goal of decreasing the cost of the procedure. The salient changes of our approach are:

\section{1) Use of Cheapest Available Drugs}

Since both intravenous melphalan and anti-thymocyte globulin are expensive and unavailable in México, we chose to use available and affordable drugs by means of the following scheme: Oral busulphan, $4 \mathrm{mg} / \mathrm{Kg}$ on days -6 and -5 ; i.v. cyclophosphamide, $350 \mathrm{mg} / \mathrm{m}^{2}$ on days $-4,-3$ and -2 ; i.v. fludarabine, $30 \mathrm{mg} / \mathrm{m}^{2}$ on days $-4,-3$ and -2 ; oral cyclosporin A (CyA) $5 \mathrm{mg} / \mathrm{Kg}$ was started on day -1 and i.v. methotrexate $5 \mathrm{mg} / \mathrm{m}^{2}$ was delivered on days $+1,+3,+5$ and $+11[7,18,19]$.

\section{2) Tailored Number of Apheresis Sessions}

We employed initially three sessions of apheresis to obtain peripheral blood HSC from the donors [18], but we learned afterwards that, with the goal of obtaining between 1 and $6 \times 10^{6}$ viable CD34 cells/Kg of recipient's body weight [12] we could cut down the number of sessions of apheresis to a median of two (range 1 to 4), thus diminishing costs of the procedures and of the disposable apheresis sets.

\section{3) Elimination of Prophylactic Ganciclovir and Intrave- nous IgG}

Probably as a result of the reduced bone marrow damage during NST, the prompt recovery of both the hematopoiesis and immune function in this type of allografts and the use of peripheral blood, there is a very low prevalence of cytomegalovirus (CMV) disease despite a high prevalence of CMV infection in these individuals. Using a pre-emptive approach for the therapy of CMV, we have faced no CMVrelated deaths in patients given NST using our method [21] and have elected to eliminate the prophylactic use of both ganciclovir and intravenous $\mathrm{IgG}$, thus reducing costs; it is interesting that other NST schedules including anti-CD52 monoclonal antibody are related to higher prevalences of CMV disease and mortality [21].

\section{4) Outpatient Conduction}

Since the duration of both granulocytopenia and thrombocytopenia during NST is shorter than those during autologous stem cell transplants or during myeloablative chemotherapy, we elected to conduct NST on an outpatient basis provided that certain conditions are fulfilled: Only patients 
asymptomatic, fully active, able to stay in their homes, with relatives or friends or in nearby-hotels, and with a fair educational level can be offered this program; fundamental to the success of this approach is the availability of a 7 day-a-week clinic where medications and transfusions can be rapidly and efficiently provided $[23,27]$. In our experience in 193 patients, only $22 \%$ were hospitalized, mainly because the development of fever or mucositis. Normal complete blood count and Karnofsky $>70 \%$ are values that reliably predict whether an outpatient stem cell transplant can be successfully completed [39]. Interestingly, we also found that the long-term disease free survival of the patients that were allografted on an outpatients basis was significantly better thatn that of those who were admitted to the hospital [39].

\section{5) Reduced Number of Blood Products Transfusions}

Stemming also from the prompt recovery of the bone marrow, NST can be conducted in some instances without transfusion of blood products. In our experience, approximately one out of three individuals does not need red blood cells or platelets transfusions: The median of transfused red blood cells units is 6 , range $0-19$, whereas the median of platelet transfusion sessions was 2 , range $0-5$. Around thirty percent of the patients given NST using our method do not require red blood cells nor platelet transfusions at all [25, 26]. It is obvious that this policy results in decreases of both costs and risks derived from exposure to human blood derivatives. Accordingly, "transfusion-free" (bloodless) allografts, can be accomplished [25, 26].

\section{6) Reduced Donor-Lymphocyte Infusions}

Donor lymphocyte infusions (DLI) are delivered only if the patients, on day 30 , have not displayed either of the following: evidence of partial or complete chimerism [23], graft versus host disease or molecular remission of the malignancy. As a result of this policy, less than $5 \%$ of the patients need late DLI, thus diminishing costs as well.

\section{RESULTS}

Using the "Mexican method" to conduct allogeneic bone marrow transplantation, we have conducted in Latin America over 400 allografts in patients with different diseases: Chronic myelogenous leukemia (CML), acute myelogenous leukemia, acute lymphoblastic leukemia, myelodysplasia, thalassemia major, relapsed Hodgkin's disease, BlackfanDiamond syndrome, adrenoleukodystrophy, Hunter's syndrome, aplastic anemia and several solid tumors. In the whole group, the median granulocyte recovery time to $0.5 \mathrm{x}$ $10^{9} / \mathrm{L}$ was 13 days, whereas the median platelet recovery time to $20 \times 10^{9} / \mathrm{L}$ was 12 days. Around one third of the patients did not need red blood cell transfusions and also one third did not need platelet transfusions [25, 26]. Around 80\% of cases the procedure could be completed tgotally on an outpatient basis. The follow up time of the patients ranges between 30 and 2000 days. Using chimerism studies, around $8 \%$ of individuals failed to engraft and, since the preparative regimen is non-myeloablative, all these patents recovered endogenous hematopoiesis. Approximately 50\% of the allografted individuals developed acute GVHD, and 30\% chronic GVHD. The median post-allograft overall survival (SV) has not been reached and the 2000 day overall SV is $54 \%$. The 100 -day mortality is $16 \%$ The best results with our method have been obtained in CML, whereas the worst were obtained in ALL; these differences may stem from the sensitivity of these diseases to the graft versus leukemia effect. The Table 1 summarizes some of the results obtained in patients with different hematological disease, using the "Mexican approach" to conduct non-ablative stem cell allografting.

In the whole group of patients, the median cost of each NST was 18000 USD [20,28], a figure which contrasts with that informed from the United States of America, where a bone marrow transplantation using conventional allografting has a median cost of 300000 USD [2]. As an example, it is clear that, nowadays, with the cost of imatinib along a 200day period, a CML patient can be allografted using our method [24, 29], this being the main reason why we have allografted CML patients in developing countries [24, 29].

Having allografted more than 400 individuals in México using the "Mexican" method to conduct NST, we are now analyzing the results of our procedure in several diseases:

In the case of chronic myelogenous leukemia, we published initially a paper of $21 \mathrm{CML}$ patients in different phases of the disease, alografted in two institutions in México (Centro de Hematología y Medicina Interna de Puebla - CHMI - and Hospital Universitario de Monterrey HUM - ) ; in this study we found a 750 day overall SV of $60 \%$ [24]. Later on, in a group of $24 \mathrm{CML}$ patients only in first chronic phase, recruited in a collaborative Group (LatinAmerican Cooperative Onco Hematology Group - LACOHG - ) with patients from six institutions located un four Latin American countries (México, Venezuela, Brasil, and Colombia), we obtained an 830-day disease free SV of $92 \%$ [29]; it was clear that the results were better allografting

Table 1. Some Features of the Allografted Patients, According to the Diagnosis

\begin{tabular}{|c|c|c|c|c|}
\hline Diagnosis & n & Age, years & Overall survival & Reference \\
\hline & \multicolumn{3}{|c|}{ (median, range) } \\
\hline \hline CML, AP & 21 & $43(20-61)$ & $60 \%$ @ 750 days & 24 \\
\hline CML, CP & 24 & $41(10-71)$ & $92 \%$ @ 830 days & 30 \\
\hline AML, CR2 & 24 & $35(12-56)$ & $66 \%$ @ 860 days & 32 \\
\hline ALL, CR2 or & 43 & $19(1-55)$ & $31 \%$ @ 1100 days & 35 \\
\hline AA & 24 & $25(4-65)$ & $91 \%$ @ 1500 days \\
\hline
\end{tabular}

$\mathrm{CML}=\mathrm{Chronic}$ myelogenous leukemia, $\mathrm{AP}=$ all phases, $\mathrm{CP}=$ chronic phase $; \mathrm{AML}=$ acute myelogenous leukemia, $\mathrm{CR}=\mathrm{Complete}$ remission; $\mathrm{ALL}=\mathrm{acute}$ lymphoblastic leukemia; $\mathrm{AA}=$ aplastic anemia. 
CML patients in first chronic phase. Recently, we have shown that, despite the fact that drug treatment is superior to allografting as first-line therapy in chronic myeloid leukemia in developed countries, allografting has still a relevant role in circumstances of limited resources, present in over $50 \%$ of the inhabitants of the world, where economic considerations can not be overlooked; cost considerations in this scenario may favor allo-SCT as a one-in-a-life-time procedure in which lifelong drug treatment with an expensive drug represents an excessive burden on resources. While allografting initial cost may be higher both to the society and the individual, it may still have a better lifetime economic value [67, $68]$.

In the case of acute myelogenous leukemias, in a collaborative study in three Mexican institutions: CHMI, HUM and Centro Médico la Raza (CMR) of the Instituto Mexicano del Seguro Social, in a group of 24 AML patients in different stages of the disease (first, second and third remission) we found an 860-day SV of 66\% [30]. These individuals were eligible for conventional allografting but were given an NST using the "Mexican method" mainly for economic reasons. Later, on, analyzing separately the results in AML according to the remission status, we found in another multicenter study a 480-days SV of $50 \%$ for patients in first remission and $15 \%$ for those in a second remission [31]; accordingly, it seems to be better to allograft patients with AML in first remission, but it is also possible to rescue some AML patients when they have achieved a second or further remission with this type of allografting.

In the case of acute lymphoblastic leukemias, the results have been disappointing. In a group of 43 ALL patients grafted in second remission or beyond we found a 3-year overall survival rate of $30 \%$ : these data are similar to those obtained with allografting after conventional conditioning and support the concept that malignant ALL cell "escape" from the graft versus leukemia effect which is more useful in other malignancies [32].

It is interesting that we have allografted also children and adolescents with the "Mexican method" [25]. Initially, it was considered that non-ablative conditioning should be offered only to aged or debilitated individuals, or with comorbidities; however it is clear that children are the ones who suffer more the long-term consequences of the aggressive conventional preparative regimens [33]. Based in this idea, we were the first to conduct non-ablative allografting in children [25], and we have found a very low prevalence of long-term complications with very adequate results, mainly in nonmalignant hematological diseases [25, 33, 34]. After our initial publication, other groups have also engaged in allografting children using reduced-intensity preparative regimens [33].

The "Mexican method" to conduct non-ablative allografting has also been used to allograft patients with aplastic anemia. In a collaborative group of four Mexican institutions (CHMI, HUM, CMR and Instituto Nacional de Cancerología - INCAN - ), 23 individuals with severe, refractory aplastic anemia were allografted using peripheral blood stem cells and we found a 1500 day SV of 91\% [35], a figure which compares favorably with those published using other types of conditioning regimens.
With the method that we have developed, we have also grafted cord blood cells [36] as well as rescued individuals with relapsed Hodgkin's disease [37]. Small groups of patients have also been allografted: Multiple myeloma, myelodysplasia, chronic lymphocytic leukemia, solid tumors, etc. $[38,43]$.

Concerning the complications of the allografting procedures and given the low hematologic and extra-hematológic toxicity of the "Mexican" conditioning regimen, we have found that the proportion of individuals who develop a nephrotic syndrome after the allograft is considerably lower than that observed in patients given other types of non-ablative conditioning [44]. By the same token, the transfusion requirements of the patients allografted with this method are very low [26, 27], and the complications stemming from cytomegalovirus reactivation are exceptional [21, 22]. Along the same line, the 100 -day mortality is $16 \%$, a figure which contrasts with that of conventional allografting than can go up to $50 \%$ [2].

We have also analyzed the significance of the HLA disparity between donor and receptor, and we have found that it is safe to conduct nonmyeloablative allografting using our approach in individuals who have either an HLA identical (6/6) or compatible (6/6) sibling donor [45].

Having increased the number of patients allografted for acute leukemia, we have found leukemic relapses: They have occurred in $60 \%$ of patients with ALL and 50\% of patients with AML. In a multicenter study (CHMI, HUM and CMR), we have found that extramedullary relapses are more frequent in patients with AML than in those with lymphoid malignancies [46] and that bone marrow relapses are more frequent and aggressive in patients allografted for lymphoid malignancies.

\section{f) The Consequences of Breaking Dogmata}

NST has been one of the most exciting developments in the treatment of hematologic malignancies in the last ten years [41, 42]; however NST should not be envisioned as an "easy way" to conduct allogeneic bone marrow transplantation [47]. Worldwide, NST is still a therapeutic modality that has been reserved for certain individuals: Aged, debilitated or afflicted by other diseases. In several centers in Latin America, NST has been adopted as the conventional method to conduct bone marrow transplantation mainly because of its affordability, even in children, adolescents and individuals eligible for conventional allografting $[25,30,32,34,41$, $43,48,50]$. Consideration of costs should not be overlooked in any part of the world, but they are particularly critical in developing countries, such as Latin American countries [48, 51]: Eighty percent of children with cancer worldwide die of the illness because lifesaving treatments, such as hematopoietic stem cell transplantation, are not available in underdeveloped countries $[48,51]$. In some developing countries, the cost of the "Mexican approach to conduct NST has been shown to be 15-20 times lower than that of a conventional allograft in developed countries.

\section{THE MATTHEW EFFECT}

A verse in the biblical book of Matthew reads: "Unto every one that hath shall be given..... but from him that hath not shall be taken away even that which he hath" supports 
the origin of the concept of "the Matthew effect", described in a classic paper in Science by Robert K. Merton [52]; he noticed that in science, credit for a discovery or knowledge tends to go to the most famous researcher associated with it rather than to the most deserving one [53, 54]. C.N. R. Rao notes that "the Matthew effect" is not uncommon even for work done in advanced countries, but hurts a person in a developing country much more because he does research with great difficulty; sometimes it takes many years to complete the work and then get no credit is very disappointing and frustrating $[52,54]$. In simple words,"the Matthew effect" means that "the rich get richer and the poor get poorer". The "Mexican approach" to conduct bone marrow transplantation has not escaped the "Matthew effect" [47, 54, 56]: the method, which has been used in several Latin American countries, and is endowed with several advantages over other procedures to conduct NST, is frequently overlooked in reviews or papers dealing with the topic $[19,55,56,60]$. We hope that the method will eventually find its place within the therapeutic armamentarium of hematologists.

\section{CONCLUSIONS}

More than $95 \%$ of the patients who have been allografted in Latin America and other developing countries using the "Mexican approach" to conduct NST could not have afforded the cost of a conventional or more expensive stem cell transplant; accordingly, this procedure has enabled doctors in Latin America to offer this therapeuituc approach to a larger number of individuals. Prospective studies will define if NST will eventually replace conventional stem cell grafting; however, very frequently in Latin American countries, the decision for a given patient is not between offering either a conventional bone marrow transplant or a NST; the decision has to be made between NST or no other effective treatment. Because of its cost, NST could be considered as an early treatment option in countries where limited resources currently prevent usual allogeneic bone marrow transplantation; role-definition and appropriate timing for this therapeutic approach in patients are required. We are in the process of learning which malignancies are more susceptible to the graft versus tumor effect, one of the main effects of NST in addition to the replacement of the bone marrow cells, and as a consequence, we are also learning in which malignancies NST is more useful. The "Mexican approach" to conduct NST has been shown to be effective for allografting individuals with malignant and non-malignant conditions. Despite the fact that most studies with reduced intensity conditioning have a relatively short follow up, there is information which indicates that the procedure is related with lower toxicities and a lower prevalence and severity of GVHD [61, 63], with a similar efficacy as that of conventional allografting. Since this method is more feasible and affordable for patients and physicians in developing countries, the number of allografts in Latin America has increased substantially, as well as the publications related to bone marrow transplantation stemming from places where this therapeutic maneuver was considered as unaffordable previous to the development of this technology [64, 67].

Despite the fact that allografting with reduced intensity conditioning may be related with several disadvantages such as mixed chimerism and relapse of the malignancy [42, 50, 56] breaking several dogmata related to bone marrow al- lografting has resulted not only in the progress of knowledge, but also in the accessibility of many patients to sophisticated therapeutic actions, in some cases, the only true curative option for these individuals [42, 50]. For inhabitants of México and Latin America, breaking dogmata has been proved to be worthwhile in the case of hematopoietic stem cell transplantation; these observations could be useful for other developing societies.

\section{REFERENCES}

[1] Alarcón-Segovia D, Ruiz-Argüelles A, Llorente L. Broken dogma: Penetration of autoantibodies into living cells. Immunol Today 1996; 17: 163-164.

[2] Thomas ED. Hematopoietic stem cell transplantation. Sci Am 1995; 272: 38-47.

[3] Odom LF, August CS, Githens JH, et al. Remission of relapsed leukaemia during a graft-versus-host reaction. A "graft-versusleukaemia reaction" in man? Lancet 1978; 2: 537-40.

[4] Weiden PL, Sullivan KM, Fluornoy N, Storb R, Thomas ED. Antileukemic effect of chronic graft versus host disease. Contribution to improved survival after allogeneic marrow transplantation. $\mathrm{N}$ Engl J Med 1981;304: 1529-1533.

[5] Hematology: Landmark papers of the twentieth century. Lichtman MA, Spivak JL, Boxer LA, Shattil SJ, Henderson ES (editores). Academic Press. San Diego, U.S.A. 2000, pp. 741-747.

[6] Kolb HJ, Mittermüller J, Clemm CH, et al. Donor leukocyte transfusions for treatment of recurrent chromic myelogenous leukemia in marrow transplant patients. Blood 1990; 76: 2462-2465.

[7] Slavin S, Naparstek E, Nagler A, Ackerstein A, Kapelushnik J, Or R. Allogeneic cell therapy for relapsed leukemia after bone marrow transplantation with donor peripheral blood lymphocytes. Exp Hematol 1995; 23: 1553-62.

[8] Slavin S, Naparstek E, Nagler A, et al. Allogeneic cell therapy with donor peripheral blood cells and recombinant human interleukin-2 to treat leukemia relapse after allogeneic bone marrow transplantation. Blood 1996; 87: 2195-2204.

[9] Giralt S, Estey E, Albitar M, et al. Engraftment of allogeneic hematopoietic progenitor cells with purine analog-containing chemotherapy: Harnessing graft-versus-leukemia without myeloablative therapy. Blood 1997; 89: 4531-4536.

[10] Slavin S, Nagler A, Naparstek E, et al. Nonmyeloablative stem cell transplantation and cell therapy as an alternative to conventional bone marrow transplantation with lethal cytoreduction for the treatment of malignant and nonmalignant hematological diseases. Blood 1998; 91: 756-763.

[11] Quesenberry PJ, Stewart FM, Becker P, et al. Stem cell transplantation without myeloablation in immunocompetent recipients. En Giralt S, Slavin S (editores): Non myeloablative stem cell transplantation. Darwin Scientific Publishing. Abingdon, Oxfordshire, UK. 2000, pp 11-16.

[12] Khouri IF, Keating M, Korbling M, et al. Transplant-lite: induction of graft-versus-malignancy using fludarabine-based nonablative chemotherapy and allogeneic blood progenitor-cell transplantation as treatment for lymphoid malignancies. J Clin Oncol 1998; 16: 2817-2824.

[13] Champlin R. Nonmyeloablative chemotherapy with allogeneic hematopoietic transplantation as adoptive immunotherapy for malignancies. En Schechter GP, Hoffman R, CTHrier SL. Hematology 1999. The American Society of Hematology Education Program Book. Washington, U.S.A. 1999, pp. 413-416.

[14] Feinstein L, Sandmaier B, Maloney D, McSweeney PA, Maris M, Flowers C, Radich J, Little MT, Nash RA, Cauncey T, Wolfrey A, Georges G, Kiem HP, Zaucha JM, Blume KG, Shizuru J, Niederweiser D, Storb R. Non-myeloablative hematopoietic stem cell transplantation. Replacing high-dose cytotoxic therapy by the graftversus-tumor effect. Ann N Y Acad Sci 2001; 938: 328-337.

[15] Storb R, Champlin R, Riddell SR, Murata M, Bryant S, Warren EH. Non-myeloablative transplants for malignant disease. En Schechter GP, Broudy VC, Williams ME. Hematology 2001. The American Society of Hematology Education Program Book. Washington, U.S.A. 2002, pp. 375-391.

[16] Childs R, Barrett. Graft-versus-tumor effects following nonmyeoablative stem cell transplantation. In Giralt S, Slavin S (edi- 
tors): Non myeloablative stem cell transplantation. Darwin Scientific Publishing. Abingdon, Oxfordshire, UK. 2000, pp. 113-126.

[17] Childs R, Clave E, Tisdale J, Plante M, Hensel N, Barret AJ. Succesful treatment of metastatic renal cell carcinoma with a nonmyeloablative allogeneic peripheral blood progenitor cell transplant: Evidence for a graft-versus-tumor effect. J Clin Oncol 1999; 17: 2044-2051.

[18] Ruiz-Argüelles GJ. Allogeneic stem cell transplantation using nonmyeloablative conditioning regimens: Results of the Mexican approach. Int J Hematol 2002; 76 (Suppl 1): 376-379.

[19] Georges GE, Storb R. Review of "minitransplantation": Nonmyeloablative allogeneic hematopoiteic stem cell transplantation. Int $\mathbf{J}$ Hematol 2003: 77: 3-143

[20] Ruiz-Argüelles GJ, Ruiz-Argüelles A, Gómez-Almaguer D, LópezMartínez B, Abreu-Díaz G, Bravo G, Jaime-Pérez JC. Features of the engraftment of allogeneic hematopoietic stem cells using reduced-intensity conditioning regimens. Leukemia Lymph 2001, 42: 145-150.

[21] Ruiz-Argüelles GJ, Gómez-Almaguer D, López-Martínez B, Ponce-de-León S, Cantú-Rodríguez OG, Jaime-Pérez JC. No cytomegalovirus-related deaths after non-ablative stem cell allografts. Hematology 2002, 7: 95-99.

[22] Ruiz-Argüelles GJ, Gómez-Rangel JD, Ponce-de-León S, González-Déctor L, Reyes-Núñez V, Garcés-Eisele J. The Mexican schedule to conduct allogeneic stem cell transplantation is related to a low risk of cytomegalovirus reactivation and disease. Am J Hematol 2004; 75;200-204.

[23] Ruiz-Argüelles GJ, López-Martínez B, Santellán-Olea MR, et al. Follow up of hemopoietic chimerism in individuals given allogeneic hemopoietic stem cell allografts using an immunosuppressive, non-myeloablative conditioning regimen: A prospective study in a single instituition. Leukemia Lymph 2002, 43: 1509-1511.

[24] Ruiz-Argüelles GJ, Gómez-Almaguer D, López-Martínez B, Cantú-Rodríguez OG, Jaime-Pérez JC, González-Llano O. Results of an allogeneic non-myeloablative stem cell transplantation program in patients with chronic myelogenous leukemia. Haematologica 2002; 87: 894-896

[25] Gómez-Almaguer D, Ruiz-Argüelles GJ, Tarín-Arzaga LC, et al. Reduced-intensity stem cell transplantation in children and adolescents: The Mexican experience. Biol Blood Marrow Transpl 2003, 9: 157-161.

[26] Ruiz-Argüelles GJ, López-Martínez B, Gómez-Rangel D, Estrada E, Marín-López A, Bravo-Hernández G, Hernández JM. Decreased transfusion requirements in patients given stem cell allografts using a non-myeloablative conditioning regimen: A single institution experience. Hematology 2003, 8: 151-154

[27] Ruiz-Argüelles GJ, Morales-Toquero A, López-Martínez B, TarínArzaga LC, Manzano C. Bloodless (transfusion-free) hematopoietic stem cell transplants: The Mexican experience. Bone Marrow Transpl 2005, 36: 715-720.

[28] Gómez-Almaguer D, Ruiz-Argüelles GJ, Ruiz-Argüelles A, González-Llano O, Cantú OE, Hernández NE. Hematopoietic stem cell allografts using a non-myeloablative conditioning regimen can be safely performed on an outpatient basis. Bone Marrow Transpl 2000; 25: 131-133.

[29] Ruiz-Argüelles GJ, Gómez-Almaguer D, Morales-Toquero A, et al. The early referral for reduced-intensity stem cell transplantation in patients with $\mathrm{Ph} 1$ (+) chronic myelogenous leukemia in chronic phase in the imatinib era: Results of the Latin American Cooperative Oncohematology Group (LACOHG) prospective, multicenter study. Bone Marrow Transplant 2005; 36: 1043-7.

[30] Ruiz-Argüelles GJ, Gómez-Almaguer D, Gómez Rangel JD, et al. Allogeneic hematopoietic stem cell transplantation with nonmyeloablative conditioning in patients with acute myelogenous leukemia eligible for conventional allografting: A prospective study. Leukemia Lymphoma 2004; 45: 1191-1195.

[31] Gutiérrez-Aguirre CH, Cantú-Rodríguez OG, González-Llano O, et al. Non-myeloablative hematopoietic stem cell transplantation is of limited value in advanced or refractory acute myeloblastic leukemia. The Mexican experience. Hematology 2007; 12: 193-197.

[32] Gutiérrez-Aguirre CH, Gómez-Almaguer D, Cantú-Rodríguez OG, et al. Non-myeloablative stem cell transplantation in patients with relapsed acute lymphoblastic leukemia: Results of a multicenter study. Bone Marrow Transplant 2007; 40: 535-9.

[33] Satwani P, Cooper N, Rao K, Veys P, Amrolia P. Reduced intensity conditioning and allogeneic stem cell transplantation in child- hood malignant and nonmalignant disease. Bone Marrow Transpl 2008; 41: 173-182.

[34] Gómez-Almaguer, González-Llano. Trasplante de células hematopoyéticas en niños. Bol Med Hosp Inf Mex 2005; 62: 85-87.

[35] Gómez-Almaguer D, Vela-Ojeda J, Jaime-Pérez JC, et al. Allografting in patients with severe aplastic anemia using peripheral blood stem cells and a fludarabine-based conditoning regimen: The Mexican Experience. Am J Hematol 2006, 81: 157-161.

[36] Mancías-Guerra C, Ruiz-Delgado GJ, Manzano C, et al. Umbilical cord blood transplantation using non-myeloablative conditioning: The Mexican experience. Hematology 2006, 11: 355-9

[37] Ruiz-Argüelles GJ, López-Martínez B, López-Ariza B. Succesful allogeneic stem cell transplantation with nonmyeloablative conditioning in patients with relapsed Hodgkin's disease following autologous stem cell transplantation. Arch Med Res 2003, 34: 242245.

[38] Ruiz-Argüelles GJ, Gómez-Almaguer D, Ruiz-Argüelles A, González-Llano O, Cantú OG, Jaime-Pérez JC. Results of an outpatient-based stem cell allotransplant program using nonmyeloablative conditioning regimens. Am J Hematol 2001, 66: 241-244.

[39] Cantú-Rodríguez OG, Gutiérrez-Aguirre CH, González-Llano O, et al. Outpatient allografting using non-myeloablative conditioning: The Mexican experience. Bone Marrow Transplant 2007, 40: 11923

[40] Ruiz-Argüelles GJ. Outpatient programs of myeloablative chemotherapy, autologous and allogeneic bone marrow transplantation. Haematologica 2000; 85: 1233-1234.

[41] Ruiz-Argüelles GJ. Non-myeloablative bone marrow transplantation. Arch Med Res 2003; 34: 554-557.

[42] Ruiz-Argüelles GJ. The Mexican approach to conduct allogeneic stem cell transplantation: Braking dogmata and facing the Matthew effect. Hematology 2005, 10 (Suppl 1): 154-160.

[43] Gómez-Almaguer D. The simplification of the stem cell transplantation procedures in developing countries has resulted in costlowering and availability to more patients. Int J Hematol 2002: 76 (Suppl 1): 380-382.

[44] Ruiz-Argüelles GJ, Gómez-Almaguer D. Nephrotic syndrome after non-myeloablative stem cell transplantation. Brit J Haematol 2006; 132: 801-802

[45] Ruiz-Argüelles GJ, López-Martínez B, Manzano C, Gómez-Rangel JD, Lobato-Mendizábal E. Significance of one human leukocyte antigen mismatch on outcome of non-myeloablative allogeneic stem cell transplantation from related donors using the Mexican schedule. Bone Marrow Transpl 2005; 35: 335-339.

[46] Ruiz-Argüelles GJ, Gómez-Almaguer D, Vela-Ojeda J, et al. Extramedullary leukemic relapses following hematopoietic stem cell transplantation with non-myeloablative conditioning. Int J Hematol 2005, 82: 262-265.

[47] Ruiz-Argüelles GJ. Simplification, not demystification nor trivialization of stem cell transplantation. Haematologica 2001; 86;E07.

[48] Barr RD. The importance of lowering costs of stem cell transplantation in devloping countries. Int J Hematol 2002: 76 (Suppl 1): 365-367.

[49] Ruiz-Argüelles GJ, Ruiz-Reyes G. El tratamiento de las leucemias en países en desarrollo. In Ruiz-Argüelles GJ, San-Miguel JF (Editors). Actualización en Leucemias. Editorial Médica Panamericana. México City, México. 1996, pp. 147-151.

[50] Ruiz-Argüelles GJ, Gómez-Almaguer D. Breaking dogmata to help patients: Non-myeloablative hematopoietic stem cell transplantation. Expert Opin Biol Ther 2004; 4: 1693-99.

[51] Chandy M. Management of hematological diseases in developing countries: Socio-economic aspects. In Schechter GP, Hoffman R, Schrier SL (Editors): Hematology 1999. The American Society of Hematology Education Program Book. Washington, U.S.A. 1999, pp. 73-76.

[52] Merton RK. The Matthew effect in science. The reward and communication systems of science are considered. Science 1968; 159: 56-63.

[53] Gibbs WW. Lost science in the third world. Sci Am 1995; 273: 7683.

[54] Ruiz-Argüelles GJ, Gómez-Almaguer D. El “efecto Mateo” en la medicina mexicana. Bol Méd Hosp Inf Méx 2003; 60: 452-453

[55] Rivera Luna R. Los problemas de la hemato-oncología pediátrica en México. Bol Med Hosp Infant Mex 2003; 60: 125-131. 
[56] Borbolla JR, González-Avante M, Siller AJ. Demystyfication versus trivialization of stem cell transplantation. Haematologica 2001; 86: E06.

[57] Giralt S. Reduced-intensity conditioning regimens for hematologic malignancies: What have we learned over the last 10 years? In Berliner N, Lee SJ, Linenberger M, Vogelsang GB (Editors): Hematology 2005. The American Society of Hematology Education Program Book. Berkeley CA, U.S.A. 2005, pp. 384-389.

[58] Ruiz-Argüelles GJ, Gómez-Almaguer D. The Mexican approach to conduct non-ablative stem cell transplantation should not be overlooked. Int J Hematol 2003; 77: 526-527.

[59] Vindelov L. Allogeneic bone marrow transplantation with reduced conditioning. Eur J Haematol 2001; 66: 73-82.

[60] Ruiz-Argüelles GJ. "The Mexican approach" to conduct nonmyeloablative stem cell transplantation. Eur J Haematol 2001; 67: 5-6.

[61] Couriel DR, Saliba RM, Giralt S, et al. Acute and chronic graft versus-host-disease after ablative and nonmyeloablative conditioning for allogeneic hematopoietic transplantation. Biol Blood Marrow Transpl 2004; 10: 178-185.

[62] Diaconescu R, Flowers CR, Storer B, et al. Morbidity and mortality with nonmyeloablative|compared with myeloablative conditioning before hematopoietic cell transplantation from HLA-matched related donors. Blood 2004; 104: 1150-1158.
[63] Pérez-Simón JA, Díez-Campelo M, Martino R, et al. Influence of the intensity of the conditioning regimen on the characteristics of acute and chronic graft-versus-host disease after allogeneic transplantation. Brit J Haematol 2005; 130: 394-403.

[64] Ruiz-Argüelles GJ. Introducción e historia del trasplante de médula ósea en México. Rev Hematol 2004: 5: 80-85.

[65] Gómez-Almaguer D, Ruiz-Argüelles GJ, Gutiérrez-Aguirre $\mathrm{CH}$ Jaime-Pérez JC. Trasplante no mieloablativo de células progenitoras hematopoyéticas: Mitos y realidades. Rev Invest Clín Méx 2005; 57: 291-297.

[66] Kassim AA, Chinratanalab W, Ferrara JL, Minseishi S. Reducedintensity allogeneic hematopoietic stem cell transplantation for acute leukemias: What is the best recipe?. Bone Marrow Transpl 2005; 36: 565-574.

[67] Ruiz-Argüelles GJ, Tarín-Arzaga LC, González-Carrillo ML, et al. Therapeutic choices in patients with $\mathrm{Ph} 1(+)$ chronic myelogenous leukemia living in México in the tyrosine kinase inhibitors (TKI) era: Stem cell transplantation or TKI's ?. Bone Marrow Transplant 2008: in press.

[68] Gajewski JL, Robinson P. Do affluent societies have the only option for the best therapy?. Leukemia 2007; 21:387-388.

(c) Ruiz-Argüelles and Gomez-Almaguer; Licensee Bentham Open.

This is an open access article distributed under the terms of the Creative Commons Attribution License (http://creativecommons.org/license/by/2.5/), which permits unrestrictive use, distribution, and reproduction in any medium, provided the original work is properly cited. 